\title{
Relevansi Keterampilan Proses Sains Dalam Pembelajaran IPA Tingkat Sekolah Dasar Dengan Materi Ajar Tematik Kelas IV Tema 2
}

\author{
Halimatun Nisa ${ }^{1}$, Miptah Parid², Arif Hidayat ${ }^{3}$, Arif Mustofa ${ }^{4}$ \\ ${ }^{1}$ Universitas Islam Negeri Sunan Kalijaga Yogyakarta, Indonesia \\ Email: halimahtuhnisa@gmail.com \\ ${ }^{2}$ Universitas Islam Negeri Sunan Kalijaga Yogyakarta, Indonesia \\ Email: paridmiptah24@gmail.com \\ 3Universitas Islam Negeri Sunan Kalijaga Yogyakarta, Indonesia \\ Email: arifh4718cipa@gmail.com \\ ${ }^{4}$ Universitas Islam Negeri Sunan Kalijaga Yogyakarta, Indonesia \\ Email: musarif33@gmail.com
}

\begin{abstract}
ABSTRAK
Penelitian ini dilakukan dengan tujuan untuk menganalisis ruang lingkup bahan ajar IPA kelas IV tema 2. Bahan ajar IPA kelas IV tema 2 diharapkan mampu menimbulkan keterampilan proses sains yang ada pada diri siswa. Metode penelitian yang digunakan dalam penelitian ini adalah metode peneltian kepustakaan, teknik pengumpulan yang digunakan adalah teknik dokumentasi. Berdasarkan materi Hemat Energi yang terdapat dalam buku teks kelas IV tema 2, guru mampu memunculkan keterampilan proses sains yang terdapat pada siswa melalui aktivitas yang terdapat dalam buku tersebut. Melalui kegiatan tersebut siswa mampu mengembangkan kemampuan dirinya baik kemampuan fisik maupun menta sebagai langkah awal untuk meningkatkan kemampuan yang dimilikinya. Kemampuan fisik dan mental tersebut pada dasarnya dimiliki oleh siswa meskipun masih sederhana dan perlu didorong untuk menunjukkan jati dirinya.
\end{abstract}

Kata Kunci: Keterampilan Proses Sains, Sekolah Dasar, Pembelajaran Tematik

\begin{abstract}
The purpose of this study was conducted to analyze the scope of science teaching materials in class IV SD 2 theme. Science teaching materials in class IV SD 2 theme is expected to be able to give rise to the science process skills contained in children. The research method used in this study is the library research method, the data collection technique uses documentation techniques. Based on the energy-saving material contained in class IV textbook subtheme 2 the teacher is able to bring up the science process skills contained in students based on the activity contained in the material. With this process skills students are able to develop the abilities contained within themselves both physical abilities and mental abilities as an initial stage to improve the abilities possessed by students.
\end{abstract}


These physical and mental abilities are basically possessed by students although they are still simple and need to be stimulated to show their true identity.

Keywords: science process skills; primary school; Thematic learning

Article history:

Received: 30-11-2020

Revised: 08-02-2021

Accepted: 12-04-2021

Copyright (c) 2020 Nisa, Parid, Hidayat, Mustofa

\section{PENDAHULUAN}

Pada abad ke-21 ini kemajuan dan perkembangan zaman terjadi sangat pesat terutama dalam bidang teknologi dan ilmu pengetahuan. Begitu pula dengan perkembangan dalam dunia pendidikan khususnya ilmu pengetahuan. Dengan perkembangan zaman di era saat ini dunia pendidikan harus melakukan suatu perubahan sistem pendidikan nasional menuju ke arah yang lebih baik, agar masyarakat khususnya peserta didik dapat menyesuaikan diri dan bersaing dengan perubahan dan perkembangan zaman yang terjadi pada saat ini dan yang akan datang. Titik berat pembangun pendidikan pada perkembangan zaman saat ini dan pada waktu yang akan datang dapat dilihat dari peningkatan kualitas dalam berbagai jenis jenjang pendidikan termasuk Sekolah Dasar.
Sekolah Dasar merupakan suatu jenjang pendidikan pada level terendah yang berlangsung selama kurun waktu 6 tahun. Pendidikan dasar sebagai tahap awal pembentukan karakter peserta didik untuk ke depannya. Pada tahap dasar inilah guru bertugas untuk menanamkan nilai-nilai positif bagi peserta didik yang akan berguna dalam kehidupannya serta pada tahap inilah anak pertama kali mendapatkan ilmu pengetahuan. Peran Orang tua dan guru dalam hal ini sangan penting dan dibutuhkan agar anak dapat menjadi manusia yang memiliki ke pribadi yang lebih baik dan cerdas secara spiritual, pengetahuan dan juga emosionalnya. Dalam hal ini dianjurkan orang tua dan guru melakukannya secara bertahap yaitu proses penanamannya disesuaikan dengan ukuran kemampuan yang dimiliki oleh anak. Pada tahap ini sebaiknya 
anak diajarkan materi pembelajaran yang sesuai dengan tingkatan usianya yang mana nantinya ilmu tersebut akan menunjang untuk berkelanjutan suatu jenjang pendidikan yang lebih tinggi lagi.

Informasi, komputasi, otomasi, dan komunikasi merupakan suatu ciri dari abad 21 yang mana dengan ciri-ciri tersebut diperlukan adanya suatu proses pembelajaran yang membutuhkan lulusan yang mampu menyesuaikan dengan perkembangan zamannya. Pembelajaran yang dulunya berpusat pada guru, guru sebagai pusat pembelajaran, pemberi informasi dan menjadi sumber belajar (teacher centered) yang mengakibatkan peserta didik tidak mampu untuk berpikir secara aktif dan ilmiah, harus diubah menjadi pembelajaran yang berpusat pada peserta didik, mereka harus lebih banyak berperan aktif dalam proses pembelajaran yaitu dengan mencari tahu informasi dari berbagai sumber belajar, dan peserta didik harus mampu memecahkan masalah, dan diarahkan untuk berfikir analisis (student centered) (Sukimarwati, 2017).
IPA merupakan suatu proses pembelajaran kreatif yang digunakan untuk memecahkan permasalahan sebab dan akibat fenomenafenomena yang ada di alam. Agar proses pembelajaran berjalan secara efektif maka bahan ajar yang digunakan harus berkualitas dan mampu membuat peserta didik lebih terampil dalam berpikir ilmiah (Acesta, 2014). Ilmu Pengetahuan Alam (IPA) adalah suatu ilmu yang di dalamnya mempelajari segala hal mengenai fenomena-fenomena alam.

Mata pelajaran IPA di Sekolah Dasar kurang disukai siswa karena dianggap sulit (Uswatun et al., 2016). Sebagai pendidik dan calon pendidik harus mampu mengubah cara berpikir peserta didik mengenai mata pelajaran IPA yang dianggap sulit oleh peserta didik menjadi pembelajaran yang menyenangkan dan mudah dipahami. Dalam proses pembelajaran IPA tahap awal yang harus guru lakukan adalah mengajak peserta didik untuk mempelajari dan membangun pengetahuan yang telah ditemukan oleh peserta didik dalam kehidupan sehari-hari mereka. Dengan mengembangkan keterampilan proses dapat memperbaiki proses 
pembelajaran di Sekolah Dasar. Pembelajaran IPA di Sekolah Dasar diharapkan mampu lebih menekankan pada proses pembelajaran secara langsung dengan melalui penggunaan keterampilan proses sains (Yulita, 2016).

Keterampilan proses sains (KPS) merupakan suatu keterampilan yang digunakan untuk memecahkan suatu masalah dan merumuskan hasilnya. Dalam melakukan kegiatan penyelidikan dapat digunakan KPS untuk menemukan pengetahuan sains. Keterampilan Proses Sains adalah suatu pengkajian sains dari segi proses, adapun hakikat sains adalah sebagai sikap ilmiah dan sebagai produk. Dengan keterampilan proses ini, peserta didik mampu mempelajari ilmu sains sesuai dengan tahapan-tahapan yang dilakukan oleh para ilmuan yaitu, melalui tahapan pengamatan, klasifikasi, inferensi, merumuskan hipotesis, dan melakukan eksperimen (Bundu, 2006).

Pada kurikulum 2013 terdapat dua buku ajar yaitu buku siswa dan buku guru yang menjadi sumber belajar wajib yang telah disediakan oleh pemerintah. Aspek ini sesuai dengan ketentuan yang terdapat di dalam Kurikulum 2013, peserta didik diajak untuk mengeksplorasi sumber belajar lain selain buku teks yang tersedia dan terbentang luas di lingkungan sekitarnya (Purnomo \& Acesta, 2017). Buku ajar merupakan suatu aspek yang sangat penting dalam proses pembelajaran sebagai penunjang agar tercapainya tujuan kompetensi pendidikan, bahan ajar berisikan tentang materi dan isi dari pembelajaran yang memudahkan guru dan peserta didik dalam kegiatan belajar mengajar (Purnomo \& Acesta, 2017).

Peran guru merupakan hal yang sangat penting untuk meningkatkan dan menyesuaikan daya nalar peserta didik dengan ketersediaan kegiatan pada buku ini. Guru dapat mengubah dan memodifikasi dalam bentuk kegiatankegiatan lain yang menyenangkan relevan dan sesuai yang sumbernya dapat berasal dari lingkungan sosial dan alam.

Banyak para peneliti terdahulu yang meneliti tentang keterampilan proses sains antara lain yaitu: pertama, analisis kemampuan berpikir kritis ditinjau dari keterampilan proses sains dan 
motivasi belajar melalui model PBL (Nugraha et al., 2017); kedua, pengaruh model problem based learning terhadap hasil belajar dan keterampilan proses sains (Janah et al., 2018); ketiga, analisis keterampilan proses sains pada pembelajaran berbasis praktikum (Lepiyanto, 2014) keempat, analisis profil keterampilan proses sains siswa sekolah dasar di kabupaten Sumedang (Rahayu \& Anggraeni, 2017); kelima, deskripsi keterampilan proses sains mahasiswa pada materi termodinamika (Darmaji et al., 2018).

Dari berbagai penelitian terdahulu yang meneliti tentang keterampilan proses sains, maka peneliti dalam penelitian meneliti tentang relevansi keterampilan proses sains dalam pembelajaran IPA tingkat sekolah dasar dengan materi ajar tematik kelas IV tema 2.

\section{METODE}

Penelitian ini menggunakan metode penelitian pustaka (library research), yaitu penelitian yang objeknya menggunakan buku guru (Anggari, A. S. et al., 2017) dan buku siswa (Anggari, A. St. et al., 2017) pada kurikulum 2013 edisi revisi 2017. Selain buku ajar hasil pembahasan juga berdasarkan dari berbagai bahan pustaka yang lain dan sesuai dengan permasalahan yang akan diteliti. Jenis data yang digunakan adalah data kualitatif yang bersifat tekstual. Sedangkan teknik pengumpulan data yang digunakan dalam penelitian adalah teknik dokumenter. kemudian data yang telah dikumpulkan akan dianalisis dengan menggunakan analisis isi (content analysis). Dan tahap terakhir yang akan dilakukan penulis adalah mendeskripsikan segala yang telah didapat dan dihasilkan secara rinci dan sistematis. Adapun tujuan dari penelitian ini adalah untuk memberikan informasi terhadap isi buku ajar tematik kelas IV tema 2 dari aspek pembelajaran IPA yang menerapkan keterampilan proses sains.

\section{HASIL DAN PEMBAHASAN}

Materi hemat energi didalam buku ajar terdapat pada subtema 2 . Buku ajar yang digunakan adalah edisi revisi Tahun 2017, Buku Guru sebagai buku pedoman guru melaksanakan proses pembelajaran di kelas dalam pelaksanaan Kurikulum 2013. Oleh karena itu, buku tersebut harus disesuaikan 
dengan amanat Kurikulum 2013.

Selain itu, dan diharapkan materi Analisis dilakukan dengan mencocokkan antara Kompetensi Inti (KI) dan Kompetensi Dasar (KD) yang tercantum pada Permendikbud Nomor 24 Tahun 2014 tentang Kompetensi Inti dan Kompetensi Dasar Pelajaran pada Kurikulum Kurikulum 2013 pada Pendidikan Dasar dan Pendidikan Menengah. KI dan KD IPA pada kelas IV terdapat pada lampiran 24 dengan KI dan KD yang terdapat didalam buku ajar mampu menumbuhkan minat dan mampu menggali potensi yang terdapat didalam diri peserta didik sehingga kegiatan pembelajaran dapat berjalan dengan efektif dan efisien. Serta mampu membawa dan menghendaki peserta didik untuk berpikir secara aktif dan kreatif dalam menemukan fakta ilmiah (Marnita, 2013).

\section{KOMPETENSI INTI KELAS IV}

1. Menerima dan menjalankan ajaran agama yang dianutnya.

2. Menunjukkan perilaku jujur, disiplin, tanggung jawab, santun, peduli, dan percaya diri dalam berinteraksi dengan keluarga, teman, guru dan tetangga.

3. Memahami pengetahuan faktual dengan cara mengamati (mendengar, melihat, membaca) dan menanya berdasarkan rasa ingin tahu tentang dirinya, makhluk ciptaan Tuhan dan kegiatannya, dan benda-benda yang dijumpainya di rumah dan di sekolah.

4. Menyajikan pengetahuan faktual dalam bahasa yang jelas, sistematis dan logis, dalam karya yang estetis, dalam gerakan yang mencerminkan anak sehat, dan dalam tindakan yang mencerminkan perilaku anak beriman dan berakhlak mulia.

Gambar 1. Kompetensi Inti (Dasar et al., 2016)

Muatan mata pelajaran IPA tentang hemat energi merupakan materi yang terdapat pada subtema 2, adapun muatan materi IPA pada subteme 2 diantaranya mengenai energi dan manfaatnya bagi kehidupan sehari-hari. Didalam materi menjelaskan tentang macam- macam bentuk energi, serta kegunaan energi bagi keberlangsungan hidup makhluk hidup yang ada di bumi. Seperti pada gambar di bawah ini peserta didik diajak untuk mengamati kegiatankegiatan apa saja dan sumber energi 
apa yang terdapat pada gambar (Kemendikbud, n.d.-b).

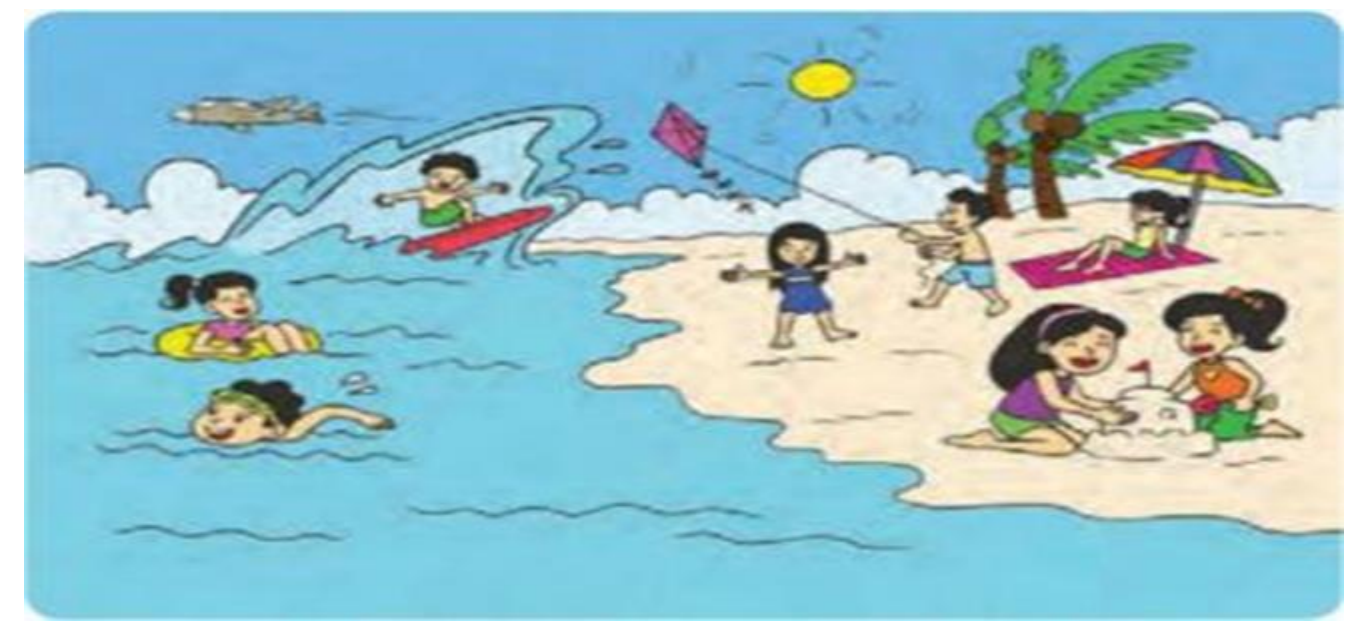

Gambar 2. Contoh Gambar Pada Buku Ajar

Melalui proses kegiatan pengamatan gambar tersebut peserta didik sudah menggunakan keterampilan proses sains dalam proses pembelajaran. Adapun keterampilan proses sains dasar untuk pendidikan sekolah dasar dan madrasah ibtidaiyah meliputi: mengamati, mengklasifikasi, mengukur, menggunakan alat, mengkomunikasikan, menafsirkan, memprediksi, dan melakukan eksperimen.

Melalui hasil pengamatan yang telah dilakukan oleh peserta didik. Peserta didik mampu menjelaskan kegiatan-kegiatan yang sedang dilakukan berdasrakan gambar yang sudah diamati adapun diantaranya, berjemur, bermain layang-layang, berenang, selancar, dan sebagainya.
Dan sumber-sumber energi yang digunakan untuk melakukan kegiatan-kegiatan tersebut diantaranya, energi cahaya dan panas matahari, energi air, gelombang air laut, energi angin, dan sebagainya. Hal ini terbukti bahwa energi sangat dibutuhkan dan sangat berguna bagi makhluk hidup saat melakukan kegiatan apapun dalam kehidupannya sehari-hari. Melalui proses pembelajaran tersebut pembelajaran akan lebih bermakna peserta didik mampu untuk menemukan sendiri konsep materi yang sedang dipelajari mereka. Kegiatan pembelajaran melalui proses pengamatan secara langsung dapat menumbuh kembangkan keterampilan proses sains (KPS) yang terdapat pada diri peserta didik (Damopolii et al., 2018). 


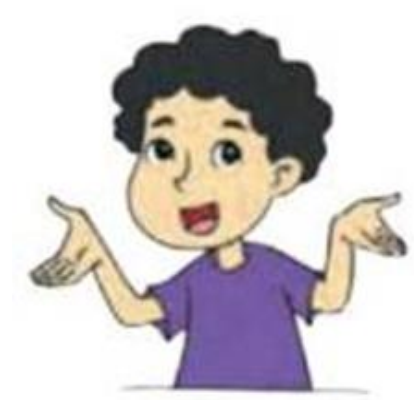

Bagaimana jika energi yang kita gunakan sudah habis?

Adakah energi penggantinya?

Apa yang dapat kita lakukan untuk

menghemat energi, ya?

Yuk, kita pelajari lebih jauh!
Kemudian berdasarkan materi subtema 2 mengenai hemat energi peserta didik diminta untuk mampu mengklasifikasikan jenis sumber daya alam yaitu sumber daya alam yang tidak dapat diperbaharui dan sumber daya alam yang dapat diperbaharui (Kemendikbud, n.d.-a). Contoh dari sumber energi yang tidak dapat diperbaharui adalah yang berasal dari batu bara, gas dan minyak bumi. Dengan terbatasnya ketersediaan sumber energi tersebut maka kemungkinan besar suatu saat nanti apabila penggunaan sumber energi tersebut dipakai secara berlebihan maka akan lebih cepat habisnya. Maka untuk memenuhi kebutuhan manusia diperlukannya sumber energi lain yaitu sumber energi alternatif.

Oleh karena itu untuk meminimalisir dampak yang akan terjadi, maka dibutuhkannya sumber energi alternatif yaitu sumber energi 176 yang dapat diperbarui, contoh dari sumber energy alternatif adalah sinar matahari, angin, air, panas bumi, gelombang laut, dan biomassa. Sumber energi alternatif yang dimaksud adalah sumber energi yang tersedia di alam yang dapat diperbaharui atau sumber energi yang tidak akan habis. Contoh sumber energi alternatif yang digunakan dan dikembangkan yaitu sumber energi yang berasal dari matahari, angin dan air.

1) Matahari

Matahari merupakan pusat dari tata surya dan menjadi sumber energi utama di muka bumi. Matahari adalah sumber energi yang memancarkan energi yang sangat besar ke seluruh permukaan bumi. Contohnya yaitu Energi panas yang dihasilkan dapat digunakan untuk membangkatkan listrik dalam sekala besar sehingga dapat 
digunakan untuk kegiatan seharihari dan memudahkan pekerjaan manusia.

2) Angin

Angin adalah aliran dari udara yang diakibatkan oleh rotasi bumi dan karena adanya perbedaan dari tekanan udara. Angin juga dapat dimanfaatkan sebagai enrgi alternatif karena energinya tidak akan pernah habis. Contoh dari pemenafaatan sumber energi angin adalah pembangkit listrik tenaga angin yaitu dengan menggunakan kincir angin tradisional atau kincir angin dapat dihungkan dengan generator sehingga akan menghasilkan listrik. Pemanfaatan dari sumber energi angin ini tidak perlu menngunakan bahan bakar sebagai sumber energinya.

3) Air

Air merupakan sumber energi gerak dan energi yang sangat penting bagi seluruh jenis kehidupan di muka bumi. Pemanfaatan Energi air biasa digunakan sebagai pembangkit listrik tenaga air. Oleh karena itu, di PLTA (Pembangkit Listrik Tenaga Air) dengan memanfaatkan kecepatan dan ketinggian air, bendungan yang digunakan untuk
PLTA dibuat di tempat yang tinggi. Energi gerak dari air terjun tersebut digunakan untuk memutar generator pembangkit listrik. Dalam pemanfaatannya air merupakan sumber energi yang tidak akan habis.

4) Panas Bumi.

Energi panas bumi adalah energi panas yang terdapat dan terbentuk dalam kerak bumi. Bumi yang terbentuk, seperti bola sesungguhnya tersusun dari lapisan-lapisan. Bumi merupakan sumber energi panas yang sangat besar. Sumber energi panas bumi dapat dimanfaatkan sebagai pembangkit istrik tenaga panas bumi.

5) Gelombang air laut

Gelombang air laut terjadi akibat adanya tiupan angin sehingga mengakibatkan gelombangnya memecah di pantai dan menghasilkan banyak energi. Energi yang berasal dari gelombang air dapat dimanfaatkan sebagai sumber energi listrik.

6) Bahan bakar bio

Bahan bakar bio merupakan bahan bakar yang dihasilkan dari bahan-bahan organik baik itu melalui makhluk hidup, hewan 
maupun tumbuhan. Bahan bakar bio memiliki banyak jenis. Contoh Bahan bakar bio yang berasal dari tumbuhan adalah tumbuhan berbiji yang mengandung minyak, seperti pohon kelapa, pohon kelapa sawit, bunga matahari, kacang kedelai dan lain-lain. Bahan bakar tersebut disebut juga dengan biodiesel. Selain itu bahan bakar bio juga dapat dihasilkan melalui hewan yaitu contohnya dari kotoran hewan. Kotoran hewan yang diuraikan dengan bantuan bakteri akan menghasilkan suatu gas bernama metana yang nantinya gas tersebut dapat digunakan sebagai sumber energi panas kompor. Selain itu, gas metana ini juga dapat digunakan untuk bahan bakar motor.

Matahari, air, dan angin merupakan energi alternatif yang dapat digunakan dan dimanfaatkan sebagai sumber energi listrik. Sumber energi listrik itulah yang dimanfaatkan oleh manusia untuk keberlangsungan hidup. Sebelum peserta didik lanjut ke materi selanjutnya, di dalam materi hemat energi ini peserta didik diajak untuk menyeselesaikan suatu permasalahan. Contoh permasalahan: untuk kebutuhan penerangan dirumahnya lani membutuhkan beberapa lampu. Berikut adalah data penggunaan lampu di rumah Lani.

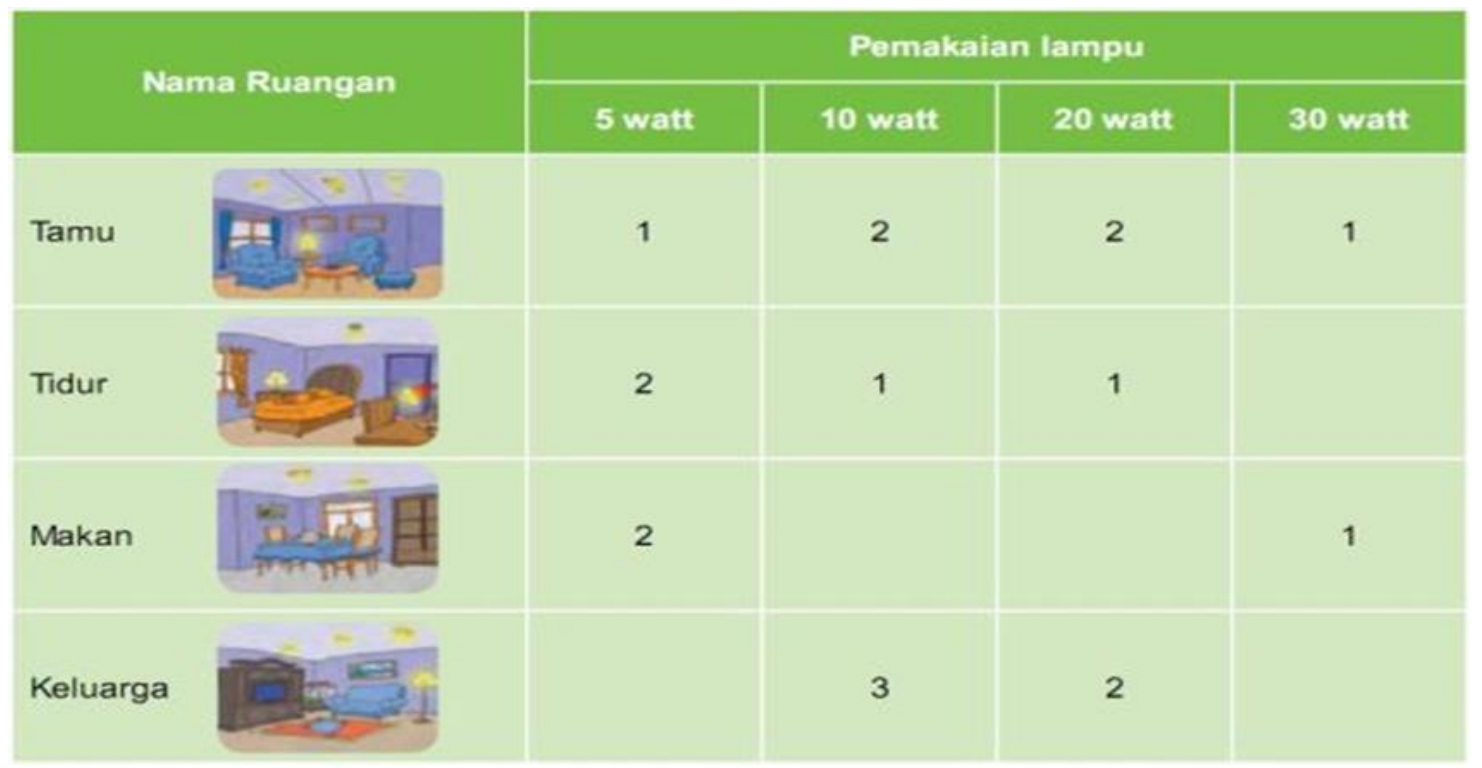

Gambar 4. Contoh Gambar Pada Buku Ajar

Setelah peserta didik mampu menyelesaikan permasalahan, maka siswa dianjurkan untuk mampu menjawab permasalahan yang telah 
diberikan. Yaitu Salah satu manfaat dari energi listrik adalah berguna sebagai penerangan. Penerangan yang dihasilkan oleh listrik dapat ditemukan di berbagai tempat contohnya di rumah, jalan, atau tempat umum lainnya. Agar lebih menarik biasanya lampu penerangan dirangkai dengan berbagai variasi. Salah satunya yaitu lampu yang di desain kelap-kelip. Biasanya lampu kelap-kelip ini mempunyai warna yang beragam dan menyala secara bergantian. Dalam pembelajaran IPA masih rendahnya kemampuan berpikir kritis peserta didik hal ini dapat dilihat dari kurangnya kemapuan peserta didik sekolah dasar dalam menganalisis sebuah masalah dan bagaimana cara memecahkan masalah tersebut agar menjadi sebuah kesimpulan. Oleh karena itu perlunya pemberian buku ajar yang baik dan berkualitas untuk menghasilkan proses pembelajaran yang efektif (Yuanita \& Yuniarita, 2018).

Hal ini sejalan dengan jurnal Ratna Prilianti tentang analisis muatan IPA materi pokok sumber energi pada buku teks pelajaran tematik terpadu MI kelas IV tema 2, bahwa guru perlu mengembangkan bahan ajar yang sudah disediakan oleh pemerintah melalui buku guru dan buku siswa pada kurikulum 2013. Berdasarkan materi hemat energi yang terdapa $t$ didalam buku ajar kelas IV subtema 2 guru mampu memunculkan keterampilan proses sains yang ada dalam diri siswa berdasarkan kegiatan-kegiatan yang terdapat didalam materi. Dengan keterampilan proses ini tujuan dari proses pembelajaran akan tercapai, yaitu dengan mengembangkan sejumlah kemampuan fisik dan mental sebagai tahap awal untuk mengembangkan kemampuan menuju tahap yang lebih tinggi pada diri peserta didik.

Pada dasarnya kemampuankemampuan fisik dan mental tersebut sudah dimiliki oleh peserta didik meskipun masih sederhana dan masih perlu bimbingan untuk menunjukkan jati dirinya. Dengan mengembangkan keterampilanketerampilan proses sains, anak akan mampu meningkatkan dan mengembangkan sendiri fakta dan konsep serta pengembangan sikap dan nilai, melalui keterampilan proses sains ini peserta didik mendapatkan pengalaman belajar secara langsung. Keterampilan 
proses sains tidak hanya dapat digunakan dalam memecahkan permasalahan yang terdapat di kelas namun dapat digunakan dalam pemecahan masalah yang ada di dalam kehidupan sehari-hari (Rahayu \& Anggraeni, 2017).

\section{KESIMPULAN}

Keterampilan proses sains untuk pendidikan sekolah dasar dan madrasah ibtidaiyah meliputi: mengamati, mengklasifikasi, mengukur, menggunakan alat, mengkomunikasikan, menafsirkan, memprediksi, dan melakukan eksperimen.

Pada tema 2 Selalu Berhemat Energi membahas tentang Sumber Energi, Manfaat Energi dan Energi Alternatif pada Kelas IV SD/MI muatan IPA hampir terdapat pada setiap kali pembelajaran. Materi menjelaskan beberapa macammacam energi dalam kehidupan sehari-hari, serta kegunaan Energi bagi makhluk hidup saat melakukan kegiatan. Dalam muatan materi ajar kelas IV tema 2 peserta didik mampu menimbulkan kemampuan keterampilan proses sains yang ada pada diri peserta didik. Dengan adanya keterampilan proses sains pada pembelajaran IPA bertujuan untuk mengembangkan serta menumbuhkan sejumlah kemampuan fisik dan mental sebagai dasar untuk mengembangkan kemampuan yang lebih tinggi pada diri siswa. Kemampuan-kemampuan fisik dan mental tersebut pada hakikatnya sudah dimiliki oleh pesrta didik meskipun masih dalam tahap sederhana dan perlu diransang lagi agar peserta didik mampu menunjukkan jati dirinya.

\section{DAFTAR PUSTAKA}

Acesta, A. (2014). Penerapan

Pendekatan Keterampilan Proses

Sains Untuk Meningkatkan Hasil

Belajar Siswa Dalam

Pembelajaran IPA. Jurnal Ilmiah

Pendidikan Dasar, 96-179.

Anggari, A. S., Afriki, Wulan, D. R.,

Puspitawati, N., Khasanah, L. M.,

$\&$ Hendriyeti, S. (2017). Buku

Guru SD/MI Kelas IV Tema 2.

Jakarta: Pusat Kurikulum dan

Perbukuan, Balitbang,

Kemendikbud.

Anggari, A. St., Afriki, Wulan, D. R.,

Puspitawati, N., Khasanah, L. M., \& Hendriyeti, S. (2017). Buku Siswa SD/MI Kelas IV Tema 2. Jakarta: Pusat Kurikulum dan 
Perbukuan, Balitbang,

Kemendikbud.

Bundu, P. (2006). Penilaian

Keterampilan Proses dan Sikap

Ilmiah dalam Pembelajaran Sains

SD. Depdiknas. Jakarta:

Depdiknas.

Damopolii, I., M, A., Yohanita,

Nurhidaya, N., \& Murtijani, M.

(2018). Meningkatkan

Keterampilan Proses Sains dan

Hasil Belajar Siswa Melalui

Pembelajaran Berbasis Inkuiri.

Jurnal Boiatika, 6(1), 22-30.

Darmaji, Kurniawan, D. A., Parasdila,

H., \& Irdianti. (2018). Deskripsi

Keterampilan Proses Sains

Mahasiswa pada Materi

Termodinamika. Berkala Ilmiah

Pendidikan Fisika.

Dasar, K., Dasar, K., Dasar, K.,

Dasar, K., Kemendikbud, Dasar,

K., ... Tarigan, P. B. (2016).

Permendikbud, nomor 24 2016,

Lampiran nomor 27, tentang

KI/KD Pendidikan Agama Hindu

dan Budi Pekerti SD. Journal of

Chemical Information and

Modeling.

https://doi.org/ 10.1017/CBO97

81107415324.004

Janah, M. C., Widodo, A. T., \&

Kasmui. (2018). Pengaruh Model
Problem Based Learning

Terhadap Hasil Belajar dan

Keterampilan Proses Sains.

Jurnal Inovasi Pendidikan Kimia.

Kemendikbud. (n.d.-a). Buku Guru

Tematik Kelas IV. Jakarta:

Kemendikbud.

Kemendikbud. (n.d.-b). Buku Siswa

Tematik Kelas IV. Jakarta:

Kemendikbud.

Lepiyanto, A. (2014). Analisis

Keterampilan Proses Sains Pada

Pembelajaran Berbasis

Praktikum. Bioedukasi Jurnal

Pendidikan Biologi.

Marnita. (2013). Peningkatan

Keterampilan Proses Sains

Melalui Pembelajaran

Kontekstual Pada Mahasiswa

Semester 1 Materi Dinamika.

Jurnal Pendidika Fisika

Indonesia.

Nugraha, A. J., Suyitno, H., \&

Susilaningsih, E. (2017). Analisis

Kemampuan Berpikir Kritis

Ditinjau dari Keterampilan

Proses Sains dan Motivasi Belajar

melalui Model PBL. Journal of

Primary Education.

Purnomo, H., \& Acesta, A. (2017).

Pengembangan Bahan Ajar dan

Penilaian Otentik Mata Kuliah

Pendidikan IPA Sekolah Dasar. 
Jurnal Profesi Pendidikan Dasar, 4(2), 22-30.

Rahayu, A. H., \& Anggraeni, P. (2017). Analisis profil keterampilan proses sains siswa sekolah dasar di kabupaten Sumedang. Pesona Dasar (Jurnal Pendidikan Dasar dan Humaniora), 5(1), 22-83.

Sukimarwati, J. (2017).

Meningkatkan Keterampilan

Proses Sains dan Prestasi Belajar Siswa Dengan Pembelajaran Guided Inquiry Model. Jurnal Florea, 4(1), 12-16.

Uswatun, D. A., Rizal, S. U., Sutisnawati, A., Aditia, R., \& Nurasiah, I. (2016).

IMPLEMENTASI COMPUTER ASSISTED INSTRUCTIONAL MODEL GAMES PADA
INTEGRATED SCIENCE DI SD. UMMI (Jurnal Penelitian dan Pengembangan Sains dan Teknologi, 10(3), 77-83. Diambil dari https://jurnal.ummi.ac.id/index. $\mathrm{php} /$ ummi/article/view/318 Yuanita, \& Yuniarita, F. (2018).

Pengembangan Petunjuk Praktikum IPA Berbasis Keterampilan Proses Untuk Meningkatkan Berpikir Kritis Siswa Sekolah Dasar. Jurnal Profesi Pendidikan Dasar, 5(2), 139-146.

Yulita, Y. (2016). Peningkatan Keterampilan Proses Sains di Sekolah Dasar Melalui Model Pembelajaran Berbasis Masalah. Jurnal Cakrawala Pendas, 2(2), 71-83. 